Jpn. J. Limnol., 51, 3, 191-197, 1990

Note

\title{
Relationship between the Yearly Changes in Phytoplankton Occurrence and Nutrient Concentration in Brackish Lake Nakanoumi, 1974-1986
}

\author{
Kunio Kondo, Yasushi SeIke and Yoshio Date
}

\begin{abstract}
Monthly surveys of phytoplankton occurrence were conducted from 1974 to 1986 at six stations in the brackish lake Nakanoumi. Both the numbers of phytoplankton cells and species tended to increase during the period when $\mathrm{T}-\mathrm{N}$ concentration sharply increased, and decreased during the period when $\mathrm{T}-\mathrm{N}$ concentration remained at the same level or gradually decreased.

Among the four diversity indices for the phytoplankton community (i.e., Patten, Shannon, Simpson and Margalef), only the Margalef index showed a highly positive correlation (coefficient $>0.7$ ) with the yearly changes of the nutrient ( $\mathrm{T}-\mathrm{P}$ or $\mathrm{T}-\mathrm{N}$ ) concentration at some stations.
\end{abstract}

Key words : brackish Lake Nakanoumi, phytoplankton, nutrient concentration, diversity index.

\section{Introduction}

Brackish Lake Nakanoumi (surface area, $97.5 \mathrm{~km}^{2}$ ) ; mean water depth, $5.6 \mathrm{~m}$; maximum water depth, $12.5 \mathrm{~m}$ ) is connected both with the Japan Sea through the Sakai Channel and with Lake Shinji through the Ohashi Channel.

Recently the water quality of the lake has deteriorated, and it has been ranked as one of the most eutrophic lakes in Japan. The phytoplankton community in this lake has varied in terms of predominant species and cell density from year to year (Онтаке et al., 1980 a, b ; Kondo et al., 1990a).

The dynamics of phytoplankton populations in brackish waters have been studied in many water areas (LenZ, 1977 ; AdmiraAl, 1977 ; Terada and Ichimura, 1979 ; Mahoney and McLaughlin, 1979 ; OHNo, 1986), but there is insufficient information on the relationship between the dynamics of phytoplankton populations and the nutrient concentration.
Wilhm and Dorris (1966) and Egloff (1973) reported that the fluctuation of environmental factors affects the diversity of phytoplankton populations. Thus, in this paper, we examined the relationships between the yearly changes in the nutrient (total phosphorus and total nitrogen) concentration and the number of species or number of cells in Lake Nakanoumi during 1974-1986. In addition, the relationship between the nutrient concentration and the diversity of phytoplankton populations was examined to elucidate the history of phytoplankton occurrence in the lake.

\section{Methods}

\section{2-1. Sampling stations and counting}

Monthly surveys of phytoplankton occurrence have been conducted since 1974 at six stations in Lake Nakanoumi (Fig. 1). Phytoplankton samples were taken from $1 \mathrm{~m}$ depth with a Van Dorn water bottle (3-liter capacity). The identification of species and cell 


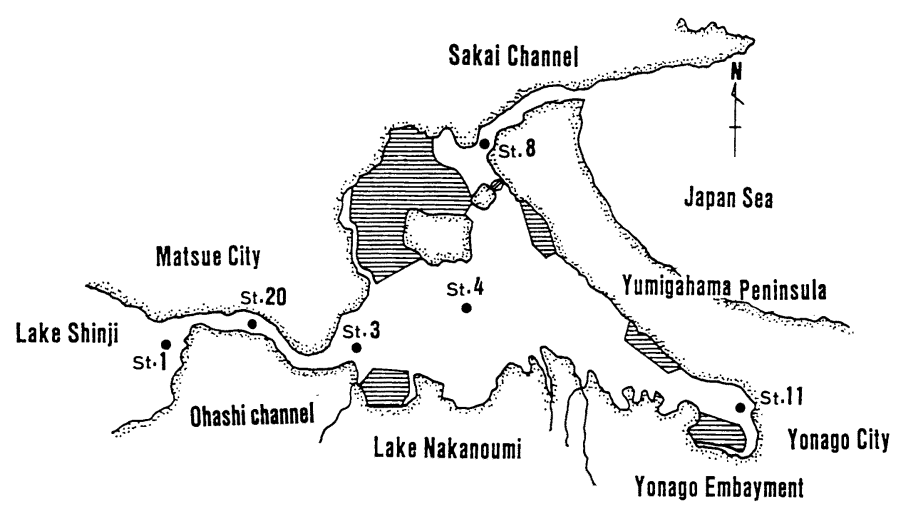

Fig. 1. Map of Lake Nakanoumi showing sampling stations (O). Hatched areas denote reclaimed lands.

counts were performed according to the method of Ohtake et al. (1980a).

The outlines of the six sampling stations were as follows : Stn. 1, salinity is the lowest among the six stations (Онтаке et al., 1980a) and the water quality is most deteriorated in Lake Shinji ; Stns. 20 and 3, water quality is influenced both by Lakes Shinji and $\mathrm{Na}$ kanoumi ; Stn. 4, water quality shows the average of the six stations ; Stn. 11, water quality is most deteriorated among the six stations; and Stn. 8 , sea water or lake water passes through this station according to the tidal rhythm.

The concentrations of total nitrogen $(\mathrm{T}-\mathrm{N})$ and total phosphorus ( $\mathrm{T}-\mathrm{P})$ were measured according to the methods of Environmental Protection Agency (1971).

\section{2-2. Calculating diversity index}

The diversity of phytoplankton populations was examined according to Eq. (1) (PAtTEN, 1962), Eq. (2) (Shannon, 1948), Eq. (3) (Simpson, 1949) and Eq. (4) (Margalef, 1967). The annual mean numbers of species and cells of each species were used to calculate the value of diversity index. The equations of four diversity indices are shown below.

$$
\begin{aligned}
& d_{1}=-\sum_{i=1}^{S} n_{i} \log _{2} \frac{n_{i}}{N} \\
& d_{2}=-\sum_{i=1}^{S} \frac{n_{i}}{N} \log _{2} \frac{n_{i}}{N}
\end{aligned}
$$

$$
\begin{aligned}
& d_{3}=1-\sum_{i=1}^{S}\left(\frac{n_{i}}{N}\right)^{2} \\
& d_{4}=\frac{S-1}{\ln N}
\end{aligned}
$$

Where $n_{i}$ is the annual mean number of cells of species $i, N$ is the total number of cells, and $S$ is the annual mean number of phytoplankton species.

The relationships between the nutrient concentration and the value of diversity index, number of species or number of cells were examined according to the linear regression analysis (CAmbell, 1974).

\section{Results and discussion}

\section{3-1. Yearly changes in concentrations of T-P and T-N}

The yearly changes in the concentrations of T-P and T-N at six stations during 1975-1986 are shown in Figures $2 \mathrm{a}$ and $\mathrm{b}$. The concentrations are given as annual mean values. The concentration of $\mathrm{T}-\mathrm{N}$ sharply increased from 1975 to 1978 at Stn. 11, and from 1975 to 1979 at other stations. The concentrations approximately doubled during the periods. The maximum $\mathrm{T}-\mathrm{N}$ concentrations were recorded in 1978 at Stn. 11, in 1979 at Stns. 3 and 4, in 1981 at Stns. 1 and 8, and in 1982 at Stn. 20. After the appearance of the peaks, the concentrations remained at the same level or slowly decreased.

The concentration of $\mathrm{T}-\mathrm{P}$ sharply increased 

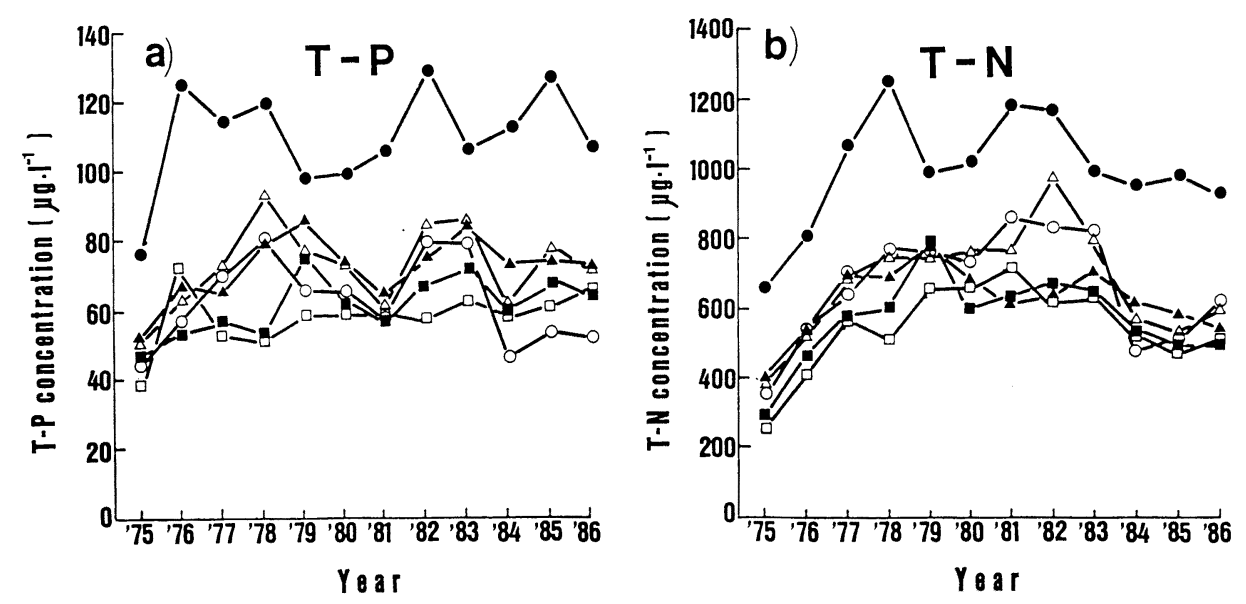

Fig. 2. Yearly changes in the concentrations of T-P (a) and T-N (b) at six stations during 19751986. The concentrations are given as annual mean values.
$-\mathrm{O}^{-}$, Stn. 1; $-\triangle^{-}$, Stn. 20;
- -, Stn. 3
- - , Stn. 4;
-, Stn. 11;
$-\square-$, Stn. 8

from 1975 to 1978 at Stns. 1, 20 and 3, and after 1980 it remained roughly at the same level. But no general trend was observed at other stations. The fluctuation of $\mathrm{T}-\mathrm{P}$ concentration showed a different pattern from that of $\mathrm{T}$ $\mathrm{N}$ concentration.

\section{3-2. Yearly changes in numbers of phyto- plankton cells and species}

Figure 3 shows the yearly changes in the annual mean values of phytoplankton cells and species observed at six stations during 1974 1986. The number of cells tended to be large during 1975-1979, except for 1977, at every station (except for Stn. 8). Red tides frequently occurred in this period (Kondo et al., 1990b). The maximum numbers of cells were recorded in 1976 at Stns. 1, 20 and 11, in 1979 at other stations. After 1980, the numbers of cells sharply decreased at Stns. 1, 20, 3 and 4, their variations were small, and they remained at the same level. The comparison of the changes in the cell numbers with the nutrient ( $\mathrm{T}-\mathrm{P}$ or $\mathrm{T}$ $\mathrm{N})$ concentration reveals that cell numbers tended to increase during the period when the $\mathrm{T}-\mathrm{N}$ concentration sharply increased, and to be small during the period when the $\mathrm{T}-\mathrm{N}$ concentration remained at the same level or gradually decreased. This tendency was obvious at
Stns. 1, 20, 3 and 4.

The number of species sharply increased from 1974 to 1978 . The maximum values were recorded in 1977 at Stns. 3 and 20, and in 1978 at other stations. After 1980, the number of species gradually decreased at every station. A large number of species was observed during the period when $\mathrm{T}-\mathrm{N}$ concentration sharply increased. Algal species such as Cryptomonas sp., Dictyosphaerium sp., Peridinium quinquecor. ne, Gomphonema sp., Achnanthes sp., Ebria tripartita and Rhoicosphenia curvata occurred only during 1977-1979 (KoNno et al., unpublished).

The relationships between the yearly changes in the nutrient concentration and the annual mean numbers of cells and species during 19751986 are shown in Table 1. The correlation coefficients between the nutrient ( $\mathrm{T}-\mathrm{P}$ and $\mathrm{T}$ $\mathrm{N})$ concentration and the number of cells at six stations were -0.10 to 0.32 for $\mathrm{T}-\mathrm{P}$ concentration, and -0.44 to 0.29 for $\mathrm{T}-\mathrm{N}$ concentration. A high correlation coefficient was not observed between them. These results indicate that the fluctuation of nutrient concentration did not directly affect the number of cells. The fluctuation of cell size of phytoplankton was neglected in this study. On the other hand, correlation 

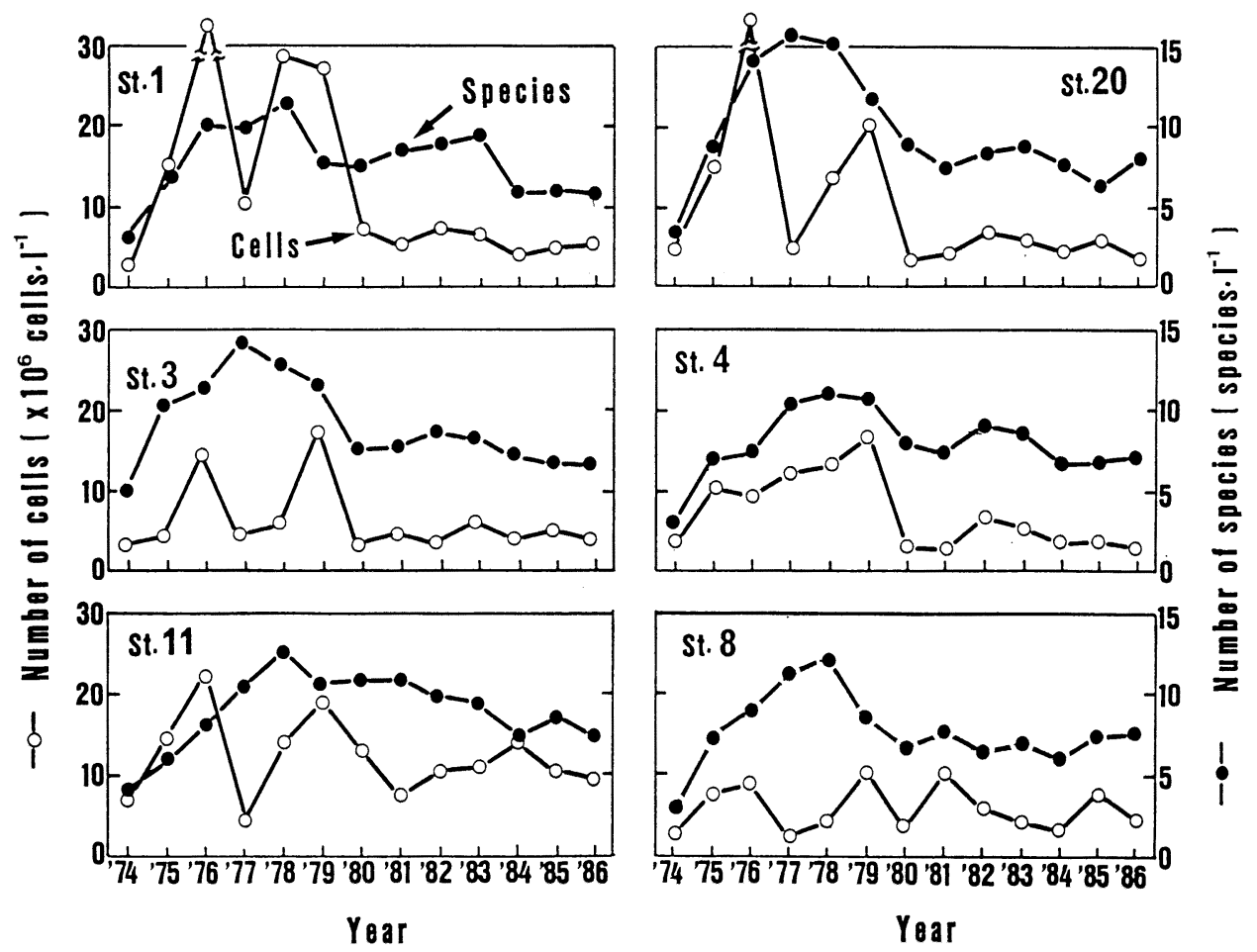

Fig. 3. Yearly changes in the numbers of phytoplankton cells $\left(-\bigcirc^{-}\right)$and number of species at six stations during 1974-1986. The numbers are given as annual mean values.

Table 1. Correlation coefficents between the nutrient ( $\mathrm{T}-\mathrm{P}$ or $\mathrm{T}-\mathrm{N})$ concentration and the annual mean numbers of cells and species at six stations during 1975-1986 $(n=12)$.

\begin{tabular}{|c|c|c|c|c|}
\hline & \multicolumn{2}{|c|}{ Num. of cells } & \multicolumn{2}{|c|}{ Num. of species } \\
\hline & $\mathrm{T}-\mathrm{P}$ & $\mathrm{T}-\mathrm{N}$ & $\mathrm{T}-\mathrm{P}$ & $\mathrm{T}-\mathrm{N}$ \\
\hline Stn. 1 & 0.14 & 0.27 & 0.74 & 0.49 \\
\hline Stn.20 & -0.20 & -0.29 & 0.22 & 0.08 \\
\hline Stn. 3 & 0.32 & 0.29 & -0.08 & 0.22 \\
\hline Stn. 4 & -0.10 & 0.19 & 0.19 & 0.63 \\
\hline Stn.11 & -0.08 & -0.44 & 0.25 & 0.83 \\
\hline Stn. 8 & 0.12 & -0.05 & -0.16 & -0.07 \\
\hline
\end{tabular}

coefficients between the nutrient concentration and the number of species were -0.16 to 0.74 for $\mathrm{T}-\mathrm{P}$ concentration (maximum, at Stn. 1), and -0.07 to 0.83 for $\mathrm{T}-\mathrm{N}$ concentration (maximum, at Stn. 11).

From these results, it was clear that the fluctuation of $\mathrm{T}-\mathrm{P}$ or $\mathrm{T}-\mathrm{N}$ concentration does not directly affect the number of cells at every station, but $\mathrm{T}-\mathrm{P}$ concentration has a close relation to the number of species at Stns. 1 and $\mathrm{T}-\mathrm{N}$ concentration at Stn. 11.

\section{3-3. Diversity of phytoplankton popula- tions}

The diversity of the Margalef index was calculated using the annual mean numbers of cells and species, and the relationships between the nutrient concentration and the value of diversity index were examined (Fig. 4). The correlation coefficients between them at six stations were 0.06 to 0.78 for $\mathrm{T}-\mathrm{P}$ concentration, and -0.17 to 0.89 for $\mathrm{T}-\mathrm{N}$ concentration. Correlation coefficients of higher more than 0.7 were observed at Stns. 1, 4 and $11: 0.78$ for T$\mathrm{P}$ concentration at Stn. 1, 0.70 for $\mathrm{T}-\mathrm{N}$ concentration at Stn. 4 and 0.89 for $\mathrm{T}-\mathrm{N}$ concentration at Stn. 11. The correlation coefficients observed at Stns. 1, 4 and 11 were higher than those observed for the relationship between the nutrient concentration and the annual mean 


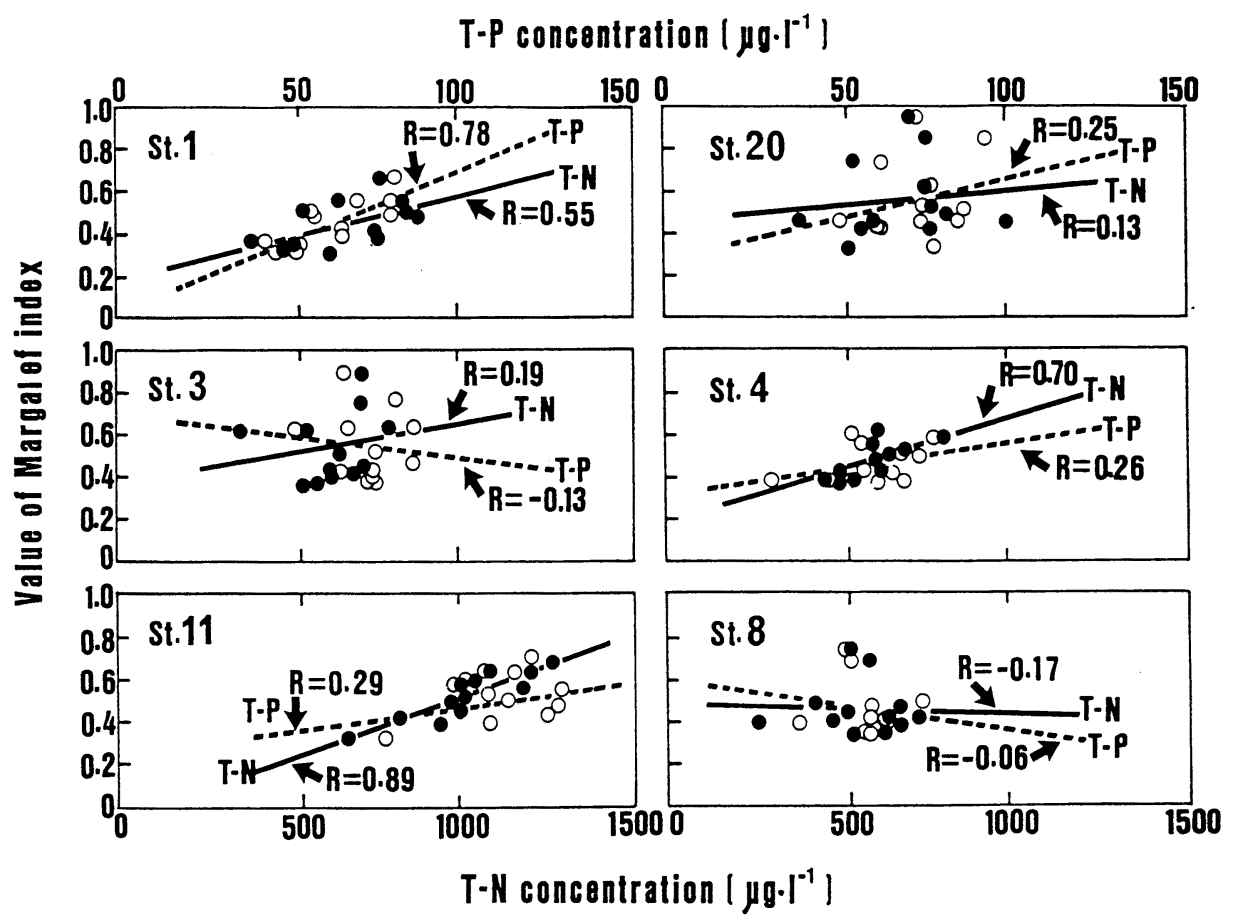

Fig. 4. Relationship between the nutrient concentration and the value of diversity of phytoplankton populations.

$\mathrm{O}$, relationship between $\mathrm{T}-\mathrm{P}$ concentration $\left(\mu \mathrm{gP} \cdot 1^{-1}\right)$ and the value of Margalef index $(n=12)$.

- relationship between $\mathrm{T}-\mathrm{N}$ concentration $\left(\mu \mathrm{gN} \cdot 1^{-1}\right)$ and the value of Margalef index $(n=12)$.

number of cells or species (Table 1). These results indicate that the dynamics of phytoplankton populations caused by on-going eutrophication at Stns. 1, 4 and 11 are well reflected in the diversity of Margalef index.

There are many theoretical or empirical diversity indices (ОкаDA and Sudo, 1976 ; Moriya, 1976), but as LLOYd et al. (1968) pointed out, it is important to examine which diversity index proves in practice to give reliable ecological predictions and insight. Therefore, the correlation coefficients between the other diversity indices and the nutrient concentration were examined (Table 2). The correlation coefficients between the nutrient $(\mathrm{T}-\mathrm{P}$ and $\mathrm{T}-\mathrm{N}$ ) concentration and the Patten index were -0.42 to 0.57 , Shannon index -0.27 to 0.50 , and Simpson index 0.12 to 0.51 . Among the four diversity indices, high correlation co- efficients were observed only in the relationship between the nutrient concentration and the value of Margalef index at Stns. 1, 4 and 11.

It is well known that the diversity of phytoplankton populations tends to decrease with water pollution or eutrophication (PATRIC, 1950 ; Wilhlm and Dorris, 1966 ; Egloff, 1973 ; YAMADA, 1982). But in this study, the diversity level such as Margalef index showed a high positive correlation to the $\mathrm{T}-\mathrm{P}$ or $\mathrm{T}-\mathrm{N}$ con centration at Stns. 1, 4 and 11. The Margalef index depends more strongly on species richness than other indices (ОкаDA and Sudo, 1976). So it is considered that the fluctuation of $\mathrm{T}-\mathrm{P}$ or $\mathrm{T}-\mathrm{N}$ concentration must strongly affect the species richness of phytoplankton populations at Stns. 1, 4 and 11 .

But in this study, a high correlation coefficient was not observed at Stns. 20, 3 and 8. As 
Table 2. Correlation coefficents between the nutrient ( $\mathrm{T}-\mathrm{P}$ or $\mathrm{T}-\mathrm{N})$ concentration and the values of diversity indices during 1975-1986 $(n=12)$.

\begin{tabular}{|c|c|c|c|c|c|c|c|c|}
\hline & \multicolumn{2}{|c|}{ Patten index } & \multicolumn{2}{|c|}{ Shannon index } & \multicolumn{2}{|c|}{ Simpson index } & \multicolumn{2}{|c|}{ Margalef index } \\
\hline & $\mathrm{T}-\mathrm{P}$ & $\mathrm{T}-\mathrm{N}$ & $\mathrm{T}-\mathrm{P}$ & $\mathrm{T}-\mathrm{N}$ & $\mathrm{T}-\mathrm{P}$ & $\mathrm{T}-\mathrm{N}$ & $\mathrm{T}-\mathrm{P}$ & $\mathrm{T}-\mathrm{N}$ \\
\hline Stn. 1 & 0.04 & 0.02 & 0.31 & 0.44 & 0.30 & 0.45 & 0.78 & 0.55 \\
\hline $\operatorname{Stn} .20$ & 0.17 & -0.42 & 0.28 & 0.50 & 0.29 & 0.38 & 0.25 & 0.13 \\
\hline Stn. 3 & 0.21 & 0.21 & 0.24 & 0.24 & 0.51 & 0.35 & -0.13 & 0.19 \\
\hline Stn. 4 & 0.57 & 0.39 & 0.46 & 0.41 & 0.51 & 0.43 & 0.26 & 0.70 \\
\hline Stn.11 & -0.03 & -0.17 & 0.14 & 0.44 & 0.12 & 0.36 & 0.29 & 0.89 \\
\hline Stn. 8 & -0.11 & -0.26 & -0.27 & 0.47 & 0.32 & 0.06 & -0.06 & -0.17 \\
\hline
\end{tabular}

mentioned above, the water quality at Stns. 20 and 3 is strongly influenced both by Lakes Shinji and Nakanoumi, and at Stn. 8 both by the Japan Sea and Lake Nakanoumi. From these results, it is considered that the examination methods used in this study are not effective for elucidating the dynamics of phytoplankton populations at Stns. 20, 3 and 8, where water current is complex.

There is little information on the relationship between the diversity of phytoplankton populations and the nutrient concentration in brackish waters (PALMER, 1977). In order to obtain ampler information on the relationship between the nutrient concentration and the dynamics of phytoplankton populations in brackish waters, further analysis are need as regards other brackish lakes.

\section{Acknowledgments}

The author is deeply indebted to Prof. N. HANDA of the Water Research Institute of Nagoya University for his critical suggestions. Thanks are also due to Prof. H. Aкіуама of Shimane University for his identification of phytoplankton species and to Profs. $\mathrm{H}$. HASHITANI and A. TAKUWA for their continuous encouragement.

\section{摘要}

\section{汽水湖中海における植物プランクトンの動態と 栄養塩濃度の関係, 1974-1986年}

1974年から1986年にわたる 6 地点での調査結果 から，汽水湖中海における植物プランクトンの動 態と栄養塩濃度との関係を検討した。年平均出現
個体数抢よび種類数は, $\mathrm{T}-\mathrm{N}$ 濃度が急速に増大し た1975年から1979年の間に大きく, T-N 濃度が横 ばいあるいは減少傾向にあった期間は減少傾向を 示した。栄養塩濃度と年平均出現個体数との間の 相関は低く, 両者関に深い関連を見いだすことが できなかったが, Stn. 1における T-P 濃度と出現 種類数, Stn. 11における $\mathrm{T}-\mathrm{N}$ 濃度と種類数との 間に 0.7 以上の比較的高い相関が認められた。

また, 栄養塩濃度と年平均出現個体数と種類数 の値を用いて算出したPatten index, Shannon index, Simpson index および Margalef index の 多様度指数との関連を検討した結果, 4 つの多様 度指数の中で Margalef index のみが, Stn. 1, 4 およびStn. 11においてそれぞれ0.78, 0.70および 0.89 と比較的高い相関が認められた。

\section{References}

Admiraal, W. (1977) : Salinity tolerance of benthic estuarine diatoms as tested with a rapid polarographic measurement of photosynthesis. Mar. Biol., 39 : 11-18.

Cambell, R. C. (1974) : Statistics for biologists. Cambridge University Press, England.

Egloff, D. A. (1973) : Stream pollution and a simplified diversity index. J. WPCF, $45: 2269$ 2275.

Environmental Protection Agency (1971) : Method for chemical analysis of water and wastes. Analytical Quality Control Lab., Ohio.

Kondo, K., Y. SeiKe and Y. DATE (1990a) : Relationships between phytoplankton occurrence and salinity or water temperature in brackish Lake Nakanoumi. Jpn. J. Limnol., 51 : 189-195.

Kondo, K., Y. SeiKe and Y. DAte (1990b) : Red tides in the brackish lake Nakanoumi (1). The frequency and causative species of red tides. Bull. Plankton Soc. Japan, 36 : 173-183.

LENZ, J. (1977) : Plankton population. p. 79-89. In G. 
Rheinheimer (ed.), Microbial Ecology of a Brackish Water Environment.. Springer-Verlag, Berlin.

LLOYD, M, J. H. ZAR and J. R. KARR (1968): On the calculation of information -theoretical measures of diversity. Amer. Midland Nat., 79 : $257-272$.

Mahoney, J. B. and J. J. A. McLaughlin (1979): Salinity influence on the ecology of phytoflagellate blooms in lower New York Bay and adjacent waters. J. Exp. Mar. Biol Ecol., 37 : 213-223

Margalef, R. (1967) : Some concepts relative to the organization of plankton. Oceanogr. Mar. Biol. Ann. Rev., 5 : 257-289.

MoriyA, K. (1976) : An ecological assessment of aquatic communities by diversity indices. J. Water and Waste, 18 : 729-748 (in Japanese).

OHNO, M. (1986) : Ecology of algae in the brackish water, p. 347-370. In M. Akiyama, Y. Aruga M. Sakamoto and Y. Yokohama (eds.), Ecology of Algae. Uchida - Roukakuho, Tokyo (in Japanese).

Ohtake, H., K. Kondo, N. Hayashi, S. Kawata and Y. DATE (1980a): Phytoplankton studies in the brackish lake Nakanoumi, 1. Phytoplankton studies in lake Nakanoumi, 1974-1978. Arch. Hydrobiol., 90 : 309-323.

Ohtake, H., Y. Date, K. Kondo and Y. Seike (1980b) : The effect the land reclamation and freshing project on the water environment in Lake Nakanumi, Jpn. J. Limnol., 41 : 153-162 (in Japanese).

OKadA, M and R. Sudo (1976) : Species diversity indices as applied to assess the water pollution. J. Water and Waste, $18: 712-724$ (in Japanese).

Palmer, C. M. (1977) : Algae and water pollution. pp. 123., U.S. EPA., Ohio.

PAtric, R. (1950) : Biological measure of stream conditions. Sewage and Industrial Waters, 22 : 926-938.

Patten, B. C. (1962) : Species diversity in net phytoplankton of Raritan Bay. J. Mar. Res., $20: 57-75$.

ShannON, C. E. (1948): A mathematical theory of communication. Bell Syst. Tech. J., 27 : 379423.

Simpson, E. H. (1949) : Measurement of diversity. Nature. $163:$ p. 688.

TERADA, T. and S. Ichimura (1979) : Environmental properties and the distribution of phytoplankton biomass and photosynthesis in a small eutrophic estuary of Shimoda Bay. La mer., 17 : 137-144.

Wilhm, J. L. and T. C. Dorris (1966) : Species diversity of benthic macroinvertebrates in a stream receiving domestic and oil refinery effluents. Am. Mid Nat., $76: 427-449$.

YAMADA, M. (1982) : Eutrophication and index of phytoplankton. p. 27-40. In Jap. Soc. Sci. Fish (ed.), Eutrophication in the estuary and biological index. Koseisya-Koseikaku, Tokyo (in Japanese).

(著者: 近藤邦男, 清家 泰, 島根大学環境安全施 設, $\bar{\top} 690$ 松江市西川津町 1060 ; 伊達善夫, 島根大 学名誉教授, 干690 松江市西川津町690；Kunio Kondo, Yasushi SEIKE, Environmental Science Laboratory, Shimane University, Matsue Shimane, 690 ; Yoshio DATE, Professor Emeritus of Shimane University, Matsue, Shimane, 690)

Received : 25 December 1989

Accepted : 18 April 1990 